\title{
5 \\ Changing Elites, Institutions and Environmental Governance
}

\author{
Benedicte Bull and Mariel Aguilar-Støen
}

\section{Introduction}

The topic of elites has always been controversial in Latin American social sciences. Elites have been studied indirectly as landowners, capitalists, business-leaders or politicians, and have also been approached directly using concepts and theory from elite studies. Although there is a significant amount of literature on the role of elites in democratic transformations (see e.g. Higley and Gunther, 1992), elites have often been considered to be an obstacle to the formation of more democratic, prosperous and egalitarian societies (e.g. Paige, 1997; Cimoli and Rovira, 2008). This is also the case in the literature on environmental governance, in which elite groups are often considered to be an obstacle to sustainable development and an obstacle to establishing more equitable influence over the use and benefits of natural resources. Therefore, although an elitist conservation movement has long existed in Latin America, struggles to protect the environment from overexploitation and contamination have commonly been related to struggles against local, national and transnational elites by subaltern groups (Martínez-Alier, 2002; Carruthers, 2008; chapters 1 and 2 in this volume).

Over the last decade a number of changes, which might have an impact on the composition and attitudes of elites, have occurred in Latin America. Such changes could have consequences for environmental governance in the broad sense of the concept, as outlined in the Introduction of this book. Out of 49 presidential elections in the 2003-2013 period, 22 were won by centre-left candidates, and with the exception of Mexico and Colombia, centre-left governments were in power in all the large economies in Latin America for most of this 
period (Bull, 2014). Many of these governments represent groups that have previously been marginalized from politics and antagonized by the elites, including indigenous and environmental movements. With the changes in the global political economy, including the rise of China and a number of other emerging economies, Latin America has also seen the entry of a number of new economic actors, including new transnational companies and new lenders. Furthermore, in key sectors, new technologies have changed the production structure and therefore also the concentration of resources - and, in turn, possibly the composition of elites.

In spite of several such changes, the initial optimism regarding implications for environmental governance has subsided. In 2010, environmentalist Eduardo Gudynas (2010) rhetorically asked the new governments: If you are so progressive, why do you destroy the environment? In the aftermath, several other questions have been posed about why governments that publicly rejected genetically modified agriculture later promoted it; why they accelerated the issuing of mining concessions in spite of protests from their former constituencies; and why they expanded logging and oil exploitation in vulnerable areas in spite of pledging to protect them.

The aim of this chapter is to provide new insight into the elite dynamics that may provide answers to some of the questions outlined above. The chapter empirically interrogates elite shifts based on six case studies, outlining how new elites have emerged, how old elites have continued to influence politics and the economy, and how the relationship between new and old elites has affected environmental governance in the region.

For our analysis we use a "resource-based" definition of elites in environmental governance: "Groups of individuals that due to their economic resources, expertise/knowledge, social networks, or positions in political or other organizations stand in a privileged position to influence in a formal or informal way decisions and practices with key social and environmental implications" (Bull, 2015: 18). This is a multifaceted definition of elites that allows for the existence of both parallel and competing elites. Nevertheless, our analysis places particular emphasis on elites that control economic resources, including business elites and landowners. Therefore below we discuss the relationship between the concept of elite and that of class, and we discuss how elites and classes are considered to contribute to or hinder democracy and development, how they might change, and how they might be thought to impact environmental governance. 
The rest of the chapter is structured as follows. The second part presents the puzzles motivating our study. In most cases these refer to environmental practices or environmental policies that were less sustainable than what was expected. Yet there are also cases in which surprising progress has been made. The third part summarizes the different problems of elites as discussed in the literature. The discussion includes the structural limitations to the transformative potentials related to a shift in the command of liberal political institutions, the predominance of "elite circulation", and what we call the "state/development" imperative based on a Weberian understanding of the need for state construction. The fourth part discusses different ways in which our case studies illustrate and confirm the problems discussed in the elite literature: how entrenched elites have hindered structural transformations towards an environmental governance that ensures more sustainable and equitable production; the conflicts over land use and how they have their roots in institutions that are kept weak due to historical control by elites; and how new governments accommodate their politics to the demands of the elites. However, some of the findings also challenge the rather pessimistic outlook of elite theory. In the fifth part we concentrate on the role of global economic transitions and technology, and elite shifts. The sixth part discusses the possibilities for change due to the emergence of new elites with different attitudes towards environmental governance. These include both new political elites and new knowledge elites. Finally, the conclusions are presented.

\section{The puzzles: Progress and setback in environmental governance under leftist governments}

In 2009, when El Salvador got its first president supported by a leftwing and former guerrilla party (Frente Farabundo Martí para la Liberación Nacional (FMLN)), it was a major break with the past. Before Mauricio Funes' electoral victory, El Salvador had been ruled for 20 years by the same business elite-led party (Alianza Republicana Nacional (ARENA)). During this period the country had undergone a major economic transformation from an agroexport country to one dependent on remittances and the service sector (Segovia, 2002). This conversion brought temporary relief to the environmental impact of agroexport-oriented agricultural production, of which the most damaging products were cotton and sugar (Hecht et al., 2006). Nevertheless, when Funes took power, the country faced a triple crisis - economic, social and environmental - which enhanced the vulnerability of the population to natural 
catastrophes. Yet the country was also characterized by significant rural as well as urban political mobilization, and by the existence of various organizations that had developed sophisticated alternatives to the conventional agricultural development model. In spite of this, the Funes government struggled hard to set El Salvador on a different path, and, in the end, new ideas related to alternative agricultural development became marginalized in the national agenda, while there was no consensus on why no new development model was allowed to emerge while the old one continued to perform badly.

In Bolivia, Evo Morales - who came to power in 2006 with his Proceso de Cambio (process of change) - gave priority to family and small-scale agriculture over industrialized agriculture. This also implied a rejection of all GM organisms due to their environmental and health implications. This position echoed the viewpoints of a broad array of social movements upon which the governing party, MAS, was based. Since coming into power, MAS has been in deep conflicts with the country's old elite, with their stronghold in the "half-moon" states (Santa Cruz, Beni, Pando y Tarija) and controlling most of the country's economic sectors, including agriculture. Paradoxically, during the government of Evo Morales, the amount of genetically produced soy in Bolivia more than doubled (Zeballos, 2012), and the question of how the government could make this compatible with the official anti-GM discourse became more and more pressing.

Argentina has also been marked by deep conflicts between the governments of Nestor Kirchner and Cristina Fernández de Kirchner of the Peronist party (Partido Justicialista) and agricultural elites. Yet, at the same time, Argentina has become one of the major producers of genetically modified soy in the world, with major implications for the structure of the agricultural sector as well as for the environment (Trigo, 2011). Why was there so little public debate about it?

In Ecuador a major puzzle regarding biotechnology also arose. A major shift in the governance of the country occurred when Rafael Correa came to power, leading a broad coalition (Alianza PAIS) with strong participation from both indigenous and environmental movements. The platform for the coalition strongly rejected GM organisms and other uses of biotechnology in agriculture. However, once in government, Correa strongly promoted their use.

The mining sector is probably the most controversial in Latin America today, with its notable expansion, and its obvious environmental and social impacts, along with the large number of conflicts mining has generated across the region (see also chapters 2 and 11). In Guatemala, 
in the silver mining project El Escobal in the south-eastern part of the country, a transnational company (Tahoe Resources Inc.) and national elites face the protests of the indigenous Xinka people and their organizations. However, in spite of stated good intentions by the government as well as the companies, repressive practices against the protesters have continued and there has been virtually no room for dialogue. We attempt to explain why it has proved so difficult to mediate between the conflicting parties.

However, there are also positive cases. In the Brazilian states of Acre and Amazonas, there have been significant improvements in forest policy and forest protection over recent years. This stands in stark contrast with the rather disappointing record regarding forest protection of the federal government during the three consecutive governments led by the Worker's Party (Partido dos Trabalhadores (PT)), those of the Luiz Inácio Lula da Silva (2003-2007 and 2007-2011) and Dilma Rousseff (2011-2014) administrations. Moreover, advances in forest governance have occurred in states governed by different parties. What can explain Acre and Amazona's success?

Environmental policies and practices are not only influenced by domestic and local politics. There are also questions to be asked of international initiatives. One of the international initiatives with the most far-reaching consequences for forest governance in Latin America at the moment is the project known as Reducing Emissions from Deforestation and Forest Degradation (REDD). In spite of its rhetoric of inclusion, not all involved parties seem to have found their views expressed in the initiative. Instead, REDD is generating its own "elite" and its own discourse, and the question is how this can really address the pressing issues in Latin America's environmental governance.

Our approach to answering these questions has been to focus on elites. Thus in the following section we will discuss what elite theory might say about the questions above.

\section{The "elite problem" in theories of development, democracy and environmental governance}

The recent increase in interest about elites and development in academic literature is closely connected to an increasing consensus about the importance of institutions for development, and the role of elites in shaping those institutions (Acemoglu and Robinson, 2012; Amsden, Di Caprio and Robinson, 2012). A focus on elites and institutions is in no way new in development theory. It has been a central element 
in Weberian-inspired development theory, from Gunnar Myrdal to the literature on the "developmental state"1 (Myrdal, 1968; Woo-Cumings, 1999). Elites have sometimes been considered a hindrance to the emergence of such a state. As argued by Myrdal, "In fact, [elites] are best defined as people who are in a position to hinder reforms or to manipulate them, and, in the end, to obstruct their implementation" (Myrdal, 2010 [1979]: 335). However, others have considered elites to be capable of the efficient and productive channelling of resources, although they have frequently also acted as rent-seekers and have directed resources towards favoured and inefficient social groups (Amsden, Di Caprio and Robinson, 2012: 5).

Much less discussed is the relationship between elites, institutions and sustainable development, a dynamic that also necessitates the analysis of environmental governance. The literature referred to above is almost exclusively focused on economic growth and industrial upgrading. Furthermore, the term "institutions" is largely equated with "state institutions", and "development" is understood as economic growth at the national level. This literature has, to a very limited degree, problematized the environmental sustainability of development, and its distributional implications are only considered to the extent that they have consequences for long-term national economic growth. In other words, distribution of the benefits of growth and development across social groups and geographical areas is only considered a problem if it leads to decelerated growth - for example, if the majority are too poor to constitute a market or lack the health and education to provide the necessary human resources.

This view of development is often rejected by the literature on political ecology that takes "Capitalism and its historical transformations [as] a starting point for any account of the destruction of nature" (Peet, Robbins and Watts, 2010: 23). What was characterized above as "development" is, in political ecology literature, considered to be the privileging of certain exploitative productive systems over others, causing intertwined distributive and ecological conflicts and the degradation of the environment (Alimonda, 2011). In the political ecology literature, however, elites are largely "black boxed". Elites appear as the perpetrators: they are the capital owners, the business and knowledge elites, and the groups controlling the state, thereby contributing to the marginalization of people inhabiting rural landscapes and to the overexploitation and pollution of natural resources (Carruthers, 2008). However, elites in the political ecology literature are rarely the object of direct scrutiny. Their interests are considered to be dependent on their location in the 
structural relations of domination, and their privileges to be derived from their positions in the structures that configure Latin America as a subaltern region open to exploitation according to the needs of a globally integrated capitalism. The double exploitation of people and nature also forms the basis of the construction of the modern states, dominated by national elites, but it is also often based on the control of natural resources and local groups in different parts of the territory (Alimonda, 2011).

Against the backdrop presented above, we should not only ask under what conditions we can expect elite objectives to be aligned with national development goals. We also have to discuss how to make those goals aligned with the interests, needs and aspirations of all population groups across social classes and territories, as well as with those of future generations. A common answer to the question of how to achieve that has been to emphasize pluralism and democracy; in other words, to ensure that there are good mechanisms of representation, participation and accountability, which can lead to the establishment of institutions of environmental governance with the potential of less elitist and more sustainable development outcomes. This has been what many hoped would occur in Latin America in recent decades after the return to formal democracies and the historical rise of previously marginalized groups to power in the government.

Elite theory has nevertheless never been convinced of the merits of pluralist democracies to make societies more egalitarian. To the contrary, elite theories of all kinds have had a quite dismal view of the potential of democracy to transform society, a matter that is partially rooted in their view of the state. Marxist elite theory, which defines elites based on their relationship to capital and means of production, is generally sceptical of the possibility for changes in the state without underlying changes in the mode of production upholding it (see e.g. Jessop, 1990). As a democratic government depends on public support, it will suffer if it presides over a serious drop in the level of economic activity as a result of conflicts with capitalists (Block, 1977). Therefore, in spite of the establishment of pluralist institutions, the state cannot really be democratized within a capitalist economy.

The other major classical political-economy theory of elites and democracy, developed by Schumpeter, was highly critical of the Marxist equation of true democracy with socialism, although not discharging the possibility that they could coexist. ${ }^{2}$ He does not have much more faith in pluralism either. Schumpeter's main point is that democracy is inherently elitist: "democracy does not mean and cannot mean that 
the people actually rule... Democracy means only that the people have the opportunity of accepting or refusing the men (sic) who are to rule them" (Schumpeter, 1976: 285). However, this should not lead one to be pessimistic about the decisions made in democratic institutions. The functioning of democracy would depend on the degree to which a government is restrained by autonomous state powers (most importantly, the judiciary), the self-restraint used by such powers (also parliamentary) and the existence of an independent bureaucracy.

The so-called "Italian school" of elite theory was also sceptical of the virtues of pluralist democracies. Originating in the writings of Mosca, Mitchells and Pareto (see Pareto 1997 [1935]; Mosca, 1939; Michels, 1962), it defines the elite as a distinct group of society that enjoys a privileged status and exercises decisive control over the organization of society (Wolf, 2012: 120). Mosca regarded universal suffrage and parliamentarism as unable to dissolve the principle that, in any society, an "organized minority" is able to "impose its will on a disorganized majority" (Mosca, 1939: 154), while Vilfredo Pareto argued that elites would slowly be replaced by ascending families and groups without changing the elitist structures of society (Pareto, 1935). Yet it is this elite circulation, not the revolutions led by the dispossessed classes, that would lead to change (Pareto, 1916, cited in Hartmann, 2007).

For this study we adopted a "resource-based definition" as outlined above, which combines some of the elements of the Italian approach with that of the Marxist approach. The definition we adopted here considers elites to potentially emerge from their control of various and possibly overlapping resources, including organizational (control over organizations, including the state), political (public support), symbolic (knowledge and ability to manipulate symbols and discourses) and personal (such as charisma, time, motivation and energy) (Etzioni-Halevy, 1997: xxv). Yet we also include a focus on the actual influence that these groups have on the environmental outcomes of changing policies and practices.

Also, our view on how elites shift is eclectic. In the Marxist view, rather than through a democratic shift of government, change would emanate from below, based on the construction of political subjects among the dispossessed classes. However, Marxism has also envisioned changes emerging from the space opened for the "relative autonomy of the state" in situations of weak or split class forces (Jessop, 1990). The capitalist classes were considered to be unable to establish a "political hegemony" by themselves, thus ensuring the dominance of the lower classes. This is rather the role of the state, which in the process assumes 
a relative autonomy from the capitalist classes (Poulantzas, 1978). This makes room for the emergence of a state elite that is functionally set apart from the capitalist class.

This is an issue that is also essential to Weber, who regards the state bureaucracy not only as a by-product of capitalism but as the most effective form of legitimate power and the source of the emergence of an entirely new class (Weber, 1978). The structure and power of the bureaucracy is much more important than the electoral institutions since the demos itself is "a shapeless mass [that] never 'governs' larger associations, but rather is governed" (Weber, 1978). The dilemma presented to new political forces gaining formal power over a state apparatus is that, while the bureaucracy may hinder a shift in policies and practices, it may take decades to construct. Irrespective of how much popular support a ruler may enjoy, without the instrument of a modern bureaucracy, his or her ability to enact, implement and enforce his or her will is severely limited.

In sum, with the exception of the Marxists, elite theorists doubt the possibility of elite-free societies. Moreover, they all have reservations against the belief that a shift in government will automatically result in a shift in elites. Nevertheless, there are venues open for change. We focus on shifts in the elites' control of resources that result in changes in their ability to exert influence over decisions and practices with environmental implications. In Latin America recently, we identified four such shifts, which will be discussed below.

\section{Leftwing governments, elite circulation and limitations to environmental governance shifts}

The first such process of change is the shift in control of political resources related to the entering of power of centre-left governments, many of which represented groups that had previously been excluded from political power, including indigenous movements, labour movements, environmental movements and diverse social movements constituted by dispossessed groups. In spite of getting electoral support from these groups, many of the governments have later disqualified or consciously attempted to co-opt some of them (Zibechi, 2010; Bowen, 2011), while new elites emerge. Thus we may observe a process of "circulation of the elites", controlling political resources with a possible impact on environmental governance.

One example of that is found in Bolivia, where groups associated with the governing party MAS have started to gain political resources and 
power (Ayo Saucedo, 2012), but also economic resources through, for example, the processes of nationalization of enterprises (Ayo Saucedo et al., 2013). The soy sector has long been dominated by a landed elite, with diverse origins (including large groups of immigrants from Brazil), but with a common discourse on the use of GM, the benefits of industrial agriculture and the desire to be independent from the Morales government (Plata, 2008; Soruco, 2008). This traditional elite still control important economic resources (particularly through their control of land). Nevertheless, a new group of people, with significantly fewer economic resources than the traditional economic and political elite, has entered the political arena and is exerting influence over the way in which the environmental consequences of GM agricultural production are addressed (Høiby and Zenteno Hopp, 2015). This new group is composed of soy farmers who have accessed their productive capacity due to contacts in the MAS party, and political groups. While standing quite far apart from the old soy elite on several matters of economic policy and so forth, they coincide with them on the issue of the desirability of expansion of GM soy. Soy production contributes substantially to government revenues and perhaps, therefore, the expansion of GM soy production into forested areas is not rejected by the government.

In El Salvador, the entering of a centre-left government had quite different consequences. El Salvador is a country that has historically been dominated by a closely knit agroexport-based elite that have had political power for most of the country's history, historically in conjunction with the military (Paige, 1997). Between 1989 and 2009 they ruled through the rightwing ARENA party, led by some of the country's richest families. Thus they awaited the coming of a government supported by the FMLN with significant fear and contempt, and the old elite put up both political and economic resistance. However, the right wing was already split when the Funes government came into power, partially due to the prior transformation of El Salvador from an agroexport- to a service-based economy dependent on remittances from migrants in the USA. Although the old elite families diversified their portfolios to benefit from the new economy (Bull, 2013), the economic transformation also produced the ascendance of new economic elites that eventually challenged the old elite dominating the ARENA party. That resulted in the breakout of the GANA party (Gran Alianza por la Unidad Nacional) soon after the Funes government took power. The Funes government attempted to include broad groups of the society in a multistakeholder dialogue to establish new forms of governance of agricultural and other productive activities. The purpose was to confront 
the grave environmental crisis in which El Salvador was submerged. The groups that advocated a different agricultural model more focused on small farms and ecological production included both members of the new government, particularly linked to the Ministry of the Environment and Natural Resources (MARN), and a broad set of civil society organizations working locally to create economies based on principles of ecology and solidarity.

However, the government could not ignore the economic crisis, with low or negative growth for many consecutive years. As predicted by Block and other Marxists, the government's dependence on the economic elites for investment limited strongly its freedom of action. The domestic economic elite also represented the political opposition, although it was split between ARENA and GANA. Although ARENA, GANA and the private sector peak association ANEP (Asociación Nacional de la Empresa Privada) initially participated in different forums of dialogue to reach solutions to pressing problems (including the Social and Economic Council established on the model of a similar institution in the EU), the relationship soon soured. The government was required to re-establish a relationship with the private sector in the context of the US-funded Alliance for Growth program, but then chose to deal directly with a narrow group of the country's most powerful businessmen in order to attempt to entice them to invest in El Salvador. In the process, however, the development plans became more and more aligned with the business elite's priorities and less and less to the groups proposing alternative models within the government (Bull, Cuéllar and Kandel, 2014). There was also an incipient economic elite emerging as a result of the policies of the new government. This had links to the governing party, but benefited from its role in the companies established with funds from the Venezuela-led Bolivarian Alliance for the Peoples of Our America (ALBA) (Lemus, 2014). However, this elite showed little inclination to support the groups within a ruling party that advocated a shift towards a more sustainable development model.

The case of Ecuador is illustrative of a different solution to similar structural constraints. When Rafael Correa came to power in 2008, it was as head of a broad coalition with support from grassroots organizations, and with a strong environmentalist faction within the government. While new groups entered the governmental corridors, these were not considered to be a new elite but rather a counterweight to the traditional elites in Ecuador that had previously - and simultaneously - incorporated and marginalized grassroots organizations (Bowen, 2011). The environmentalists in the government were able to influence 
how environmental issues were framed in the official discourse, and important changes in the status of the environment and its relation to human activity were introduced to the constitution of the country (Andrade, 2012; Basabe, Pachano and Acosta, 2012). One of the changes made was that the government openly rejected GM organisms.

However, Correa's government was equally challenged by old elites that, although lacking a recent past of 20 years of relatively stable rule that ARENA in El Salvador had enjoyed, were equally enmeshed in the international economy (both countries converted to US dollars in 2000) and had enjoyed strong privileges in association with multinational companies in the past. Yet Correa managed to challenge the old elites to a quite different extent than his El Salvadoran counterpart by ensuring income from the oil industry, strengthening the incipient mining industry and engaging in a process of strengthening the Ecuadorean state.

During Correa's second term (2009-2013) his political project was increasingly formulated as that of a developmentalist project, resting on the parallel strengthening of technology and industrial upgrading and the intensification of resource extraction. This resulted in the weakening of the environmentalist faction of the government and in the emergence and gradual strengthening of a young technocratic elite. This elite not only supported the industrialization efforts but also had a positive view on GM organisms. These young professionals, owing their influence to specialized knowledge of biotechnology, are becoming key players in defining strategies to achieve the diversification of agricultural production in Ecuador. Their view fits well with the developmentalist ideas pursued by Correa, seeking rapid diversification of the Ecuadorian economy led by experts and guided by scientific knowledge (SENPLADES, 2013). While these ideas made room for the influence of this new technocratic elite, it is also the case that the emergence of the technocratic elite reinforces and supports the plan.

Thus in the cases above we have seen the entry of new political groups in government that have struggled against old elites in their pursuit of political and economic projects. However, in the process, new elites have formed based on access to economic- and knowledge-based resources in addition to political ones. Yet the elite circulation we have seen in Ecuador and Bolivia has had a limited positive environmental impact, as requirement for funding for social projects, the strengthening of the state, and the continued struggle against old elites have often weighed stronger than environmental concerns. Moreover, emerging new elites have had equally strong economic interests in the continuation of an extractivist model, while political elites (particularly in the 
case of Ecuador) have sought support from groups controlling a technical knowledge and ideology of continued industrialization and the conquering of nature.

\section{The role of global economic transitions and technology}

The second process of elite change is a shift in the control of economic resources due to changes in the global economy. Parallel to the socalled "left tide" in Latin America, three major interrelated trends have occurred in the global economy: a rise in the demand and prices of commodities; the strongly related rise of China as a major economic power, lender and investor in Latin America (Durán Lima and Pellandra, 2013); and the strengthening of regional integration schemes such as ALBA, MERCOSUR and UNASUR, which have favoured the emergence of new economic elites associated with, for example, state-controlled or supported companies. These processes have enabled new groups to control significant shares of the economy.

The rise of China and booming commodity prices have allowed the South American countries to speed up debt repayment to international institutions, and to form new economic alliances. This has resulted in a decrease in importance of elites that have traditionally been very influential in the region, among them those related to Western multinational companies, the World Bank, the IDB and the International Monetary Fund. As a result we are currently observing new relationships and arrangements between national states on the one hand and, on the other hand, diverse international elites of various origins, including North American, European, Chinese and Latin American.

In all of the cases discussed here there has been, to a certain degree, an interplay with commodity prices, particularly the booming of the soy market and the opportunities that new elites have had to emerge. One case in particular, Guatemala, suggests that when rising commodity prices have resulted in the entrance of new transnational elites to the country, the scope of possibilities to influence environmental governance and outcomes of these new elites is limited not only by the features of the industry (i.e. mining) but also by the dynamics found in the relationship between new elites controlling access to markets and technology, and old elites controlling political resources and land. New transnational elites have opted to operate within a status quo determined by the power that the traditional elite holds over major knobs of the economy and the government, and a series of corrupt practices and relationships between the old, entrenched elite and the government 
(Aguilar-Støen, 2015). Guatemalan business elites have been successful in keeping transnational elites, including transnational companies from Canada, Australia, the USA and Russia, in a subordinate position. This is explained by the control of different but complementary resources. Domestic elites control important political resources, networks and information; transnational companies could not operate without such resources (Schneider, 2012; Bull, Castellacci and Kasahara, 2014). Local elites have also established different types of partnership with transnational mining companies. In many cases, local elites have interests in junior mining firms that are subsidiaries of transnational mining companies. The drafting of mining legislation in Guatemala involved the participation of Canadian and Guatemalan businessmen, and the resulting mining law disproportionately favours mining companies over the interests of local populations, including their environmental concerns (Dougherty, 2011). A mix of local and foreign capital finances mining operations in Guatemala. Canadian groups in association with Guatemalan capital dominate metallic mineral exploitation. The largest non-metallic mining company is the Guatemalan company Cementos Progreso, which makes the second largest contribution to mining investments in Guatemala (Lee and Bonilla de Anzueto, 2009). Mining contributed 2\% to the GDP in 2013 but it is estimated that, with the development of planned exploitation, mining could contribute approximately $4 \%$ in the future (Lee and Bonilla de Anzueto, 2009). This growth, however, is expected to occur in a context where $51 \%$ of the population of the country ( 15 million) live in rural areas and rely on agriculture for their livelihoods.

Mining operations have caused massive protests and discontent among local populations in Guatemala. One of the main reasons is that the law does not require companies to inform communities about mining operations before applying for licences. In this context, local communities have felt that their opinion has not been considered before mining operations have started, something to which they are entitled by law. Another source of discontent is that mining royalties were reduced from $6 \%$ to $1 \%$ by a new mining bill (Decree 48-97) and this is perceived among the general Guatemalan population as extremely unfair. Another source of conflict is that mining projects are often established in areas with longstanding conflicts related to access to land and land tenure, before the conflicts have been resolved. In most cases the government has responded to the demands of participation from the local population and to the protests with violence and repression. Also, as a response to the complaints regarding royalties, the Chamber of Industry unilaterally decided to propose a voluntary agreement by way of which 
mining royalties could, based solely on the decision of mining companies, be increased from $1 \%$ to $3 \%$ for gold and from $1 \%$ to $4 \%$ for silver, whereas for other activities - such as cement production controlled by a Guatemalan family - royalties were kept at $1 \%$. The government is then supposed to launch agreements with local authorities regarding royalties in their communities. This has been strongly rejected by local populations.

In Argentina there has been quite a different process of elite shift dependent on a combination of technological shifts, a changing world market and political changes. Soy production in the Pampa region in Argentina started to expand after GM soy was legalized in 1996, but it soon expanded in magnitude in other parts of the country as well, currently occupying approximately 22 million $\mathrm{Ha}$, which is between $50 \%$ and $60 \%$ of all the cultivated land in Argentina (USDA, 2013). However, rather than being predicated on the entry of a new governing elite, it has generated a shift in economic elites. As its leftwing government has drawn its main leaders from the ranks of the Peronist party, it can hardly be considered a new political elite in Argentina. However, soy production has generated shifts in the power relations among agricultural producer groups. Although not completely displacing the traditional landowning elite, new groups related to agribusiness have gained significant influence in the governance of agricultural production. This group is composed of agricultural producers, utilizing a management model in which several individuals or companies have different roles in the system, from renting land from landowners to administering external investments and managing the total production (Benchimol, 2008). They run what is commonly called "agroenterprises", in which landowners, contractors and investment brokers are involved. Such agribusinesses agreements can take the form of investment funds, agroassociations (pools de siembra), financial trust coalitions and simple contract alliances, among others. The most recent attempt to quantify it argued that agroenterprises are responsible for about $70 \%$ of total grain production in Argentina (Barri and Wahren, 2010). Today the figure is probably higher.

At the same time as the soy expansion generated a new agricultural (but not necessarily rural) elite, the strained relations between the four governments of the Kirchners (two of Néstor Kirchner and two of Cristina Fernández de Kirchner) and the traditional agriculturalists contributed to the speed of the soy expansion. The main reason behind the conflicts was the increase in export taxes on agricultural products, particularly during the first government of Cristina Fernández de Kirchner. However, conflicts also arose due to the perceived lack of 
governmental support for and interest in agriculture in general, due to lack of both predictability in "framework conditions" (including adjustments in export taxes) and technical support. This contributed to a weakening of the influence of the old rural elite (Zenteno Hopp, Hanche-Olsen and Sejenovich, 2015). Moreover, in a context characterized by high levels of uncertainty for many farmers, many of them either leased the land to agrientreprises for soy production or turned to soy production since its profitability was considered almost guaranteed over time (Calvo et al., 2011). While depending on transnational companies, first and foremost Monsanto for seed and fertilizer, there has also been a prolonged conflict between Argentinean farmers and the agricultural giant. Argentinean farmers first objected to paying royalties for the fertilizer Roundup Ready as Monsanto had failed to obtain a valid patent for it in Argentina, and later farmers opposed the payment of new royalties for the new soy seed BTRR2.

Initially it was also argued that GM soy would result in less environmental impact than conventional soy. It was argued that soy production would minimize soil cover loss due to the no-till method, and that the use of the herbicide glyphosate would prevent the use of other, and more toxic, agrochemicals applied in conventional production (Bindraban et al., 2009). GM soy soon acquired a privileged position among the nation's exports and also became a main source of governmental income. Currently the production of GM soy generates approximately one-tenth of the GDP and one-quarter of the nation's export value (Loman, 2013). The conversion to the GM soy model generated a net value of US\$65,435 million for Argentina between 1996 and 2010, due to savings in costs and higher profitability (Trigo, 2011). This source of funding has been of key importance for the government's ambitious programmes of social redistribution. Added to this, the economic interest by national and international agribusiness companies explains the government's unwillingness to impose more ambitious environmental guidelines on GM soy production. Only very recently has there been a broader public debate due to increasing opposition against and conflicts related to soy production, exposing the severe soil degradation resulting from soy production and glyphosate's negative impact on human health, among other issues (Skill and Grinberg, 2013).

\section{The role of knowledge and the contours of elite reorientation}

However, we also see the contours of a third process: "elite reorientation", or, in other words, the shift in the dominating ideas of an elite. 
Both Schumpeter and Weber emphasized the orientation and capacity of elites as a major factor in understanding the role of the state in development, rejecting that this could be directly inferred from their position in the capitalist economy (as the Marxists would argue). In recent Latin American history we have two major examples of such elite reorientation: the process of democratization of the 1980s and 1990s, and the neoliberal transformation in the same period. Neither processes of elite reorientation happened out of the blue. Rather, the new ideas achieved influence due to a crisis and exhaustion of prior models and a gradual shift in interests. Currently the seriousness of the environmental crisis, and the climate crisis more specifically, could open up space for new ideas brought about by new elite groups, the reorientation of old groups, or a new dynamic interplay between different elite groups.

Despite the numerous contradictions evident in the environmental policies pursued by Brazil's three leftwing governments (two under Luis Inácio Lula da Silva and one under Dilma Rousseff), in the Amazonian states of Acre and Amazonas a shift in elites and in the environmental policies pursued in these states occurred at the state level. Despite the differences (in size among other things), around 2009/2010, Acre and Amazonas were the least deforested states in Brazil, with small Acre having lost $14 \%$ of its original forest and Amazonas only 3\% (Lemos and Silva, 2011). Our research found that this was closely related to a shift in elites occurring in different ways. The turning point in Acre was the coming to power of the PT candidate in 1998, whereas in Amazonas it occurred as a candidate linked to the old elites shifted towards a more environmentalist and less developmentalist strategy to distance himself from the old ruling elite in order to gain votes in the local elections of 1992 (Toni, Villarroel and Taitson Bueno, 2015). Thus the process at the local level has been very different from that at the federal level. At the federal government level an "elite settlement" between economic elites and rightwing parties, on the one hand, and elites of the leftwing parties, on the other hand, has led to the favouring of developmental goals over the environment (Arretche, 2013). In contrast, at the state level there has been some room for elite shifts through elite reorientation. The autonomy given to lower politicoadministrative levels in the federal model has thus been crucially important for the latter process.

Global initiatives, such as REDD, are also fostering a possible "elite reorientation" through the emergence of a new knowledge-based elite that is organized in wide and often transnational networks. These networks have been able to influence the attitudes and strategies of certain elites, although this has not implied a complete reorientation of old 
elites (i.e. those linked to agroexport activities) or of government elites, particularly because of the centrality of resource extraction in economic growth in the region (Aguilar-Støen and Hirsch, 2015). The global REDD initiative was launched at the climate negotiations in 2005 but only gained political traction in 2007, when donor governments agreed to commit substantial economic resources to establish a fund that would pay developing countries not to deforest. The principle of REDD is relatively simple: it is based on the idea that it is possible to pay countries and communities for not cutting down their forests. However, the implementation of REDD is not so simple. Latin America is endowed with vast amounts of forested land but as a whole the region has the world's highest rate of deforestation (Hall, 2012). Because of that, much attention and efforts have been invested in trying to successfully develop REDD projects in the region. These projects are, to date, only demonstration activities that will allow implementers to understand how REDD would work on the ground. That means understanding how payments are to be implemented and to whom, how to monitor that the area covered by forest is effectively not deforested, and how to ensure that economic benefits are distributed in a fair manner among those that contribute to forest conservation and constitute a legitimate beneficiary of REDD. Since forests are valuable for a range of different actors, from forest-dwellers to drug cartels, control of forested land is a contested issue and thus establishing national or local REDD projects is a complex task. In addition, many valuable non-renewable resources, such as minerals and oil, are often located in forested areas and several governments in Latin America have declared extractive activities as being key to national economic development. REDD has attracted the attention of various and disparate actors, including environmental NGOs, research centres, extractive industry companies, indigenous peoples' organizations and international development agencies.

REDD is a broad and vague enough idea to allow different interpretations of it that can fit the goals of different actors (Angelsen and McNeil, 2012). This has allowed these actors to distinctly define the actions necessary to implement REDD at local levels. In the process, certain narratives, values and visions gain prominence and those promoting such ideas gain power to define how REDD should look in specific contexts. Controlling the production of knowledge seems to be a prominent strategy of different actors to position themselves in the REDD debate, particularly in the countries in the Amazon basin (Aguilar-Støen and Hirsch, 2015). The knowledge required to participate in the REDD debates is not just any type of knowledge. It has to 
be maintained and strengthened through particular networks, in which different concepts and arguments are socially constructed and legitimated through complex processes that have produced new dominant forms of expertise and consultancy (Fairhead and Leach, 2003; Bumpus and Liverman, 2011). These networks that are coalitions of actors who share values, interests and practices can be conceptualized as elites insofar as they control key resources: the production and promotion of specific knowledge or forms to generate knowledge and access to policymaking forums. Ideas, values and resources circulate within networks, and as such the networks may set the limits or boundaries of how reality is to be understood or to set apart what constitutes expert and non-expert knowledge. A range of different private actors and companies support REDD activities, forming alliances and promoting certain models, particularly those that are positive to carbon markets. In this way, REDD is offering a new regime of profit-making possibilities in the trade of carbon offsets, but also in fostering the development of new forms of consultancy and expertise. REDD science-policy networks are influencing, although not necessarily reorienting, the position of other elite actors. For example, various transnational and national companies, such as mining and energy-producing companies, plantation companies, forestry companies and carbon-market companies, engage in REDD demonstration activities by funding specific projects. Since dominant REDD science-policy networks have ideological positions that do not conflict with the ideological position of corporations, it has been possible to establish alliances between them. But since resource extraction continues to be central to the economies of most Amazon countries (Bebbington and Bebbington, 2012), often at the expense of forests, the degree to which REDD elites can influence other elites is limited. Mining, gas and oil extraction are the most important activities to generate economic revenues for most of the countries in the Amazon basin. The development of infrastructure such as hydropower and road-building are also priorities for these countries. All these activities are, in most cases, planned to occur in forest areas. In addition, the agricultural frontier is expanding in many Latin American countries. Therefore we cannot affirm that REDD elites have a strong influence in the Amazon countries' broader development policy-making or in the national visions of development, but REDD elites have indeed been successful in engaging actors from the agricultural and industrial sectors in the funding of demonstration activities.

Taken together, the cases of Brazil and of REDD show that a shift in elites sometimes leads to more ambitious environmental goals and 
regulations. Whether or not this happens depends on the degree to which new elites are able to influence the positions and views of old elites. Chapter 6 suggests that the views, aspirations and environmental orientation of elites are not homogeneous. It is conceivable that we will see the ascendance of elites in the future with aspirations of a more sustainable development policy and environmental governance. It is also necessary to remember that centre-left governments in Latin America won the elections thanks to the support of wide segments of the population, particularly the marginalized and subaltern ones. These governments depended on various types of alliance between different grassroots organizations and social movements. If these movements and grassroots organizations are able to exert some pressure on their governments to address environmental concerns in the future, we may see a shift towards more equitable and sustainable models of environmental governance. If popular mobilization continues to be crucial for maintaining leftist governments in power, at some point the environmental concerns of the population need to be addressed.

\section{Conclusion}

Back in 1977, Marxist scholar Fred Block rejected the possibility that a leftwing government in power could make a significant change to the productive structure of a country, as any government presiding over a capitalist economy inevitably has to care about the creation of employment and economic growth, and therefore would never counter the interests of the capitalists. Over the last decade we have seen a multitude of strategies applied by leftwing Latin American governments to overcome the constraints presented by old elites that are often also political adversaries. Although, judging from media reports, the relationship between the centre-left government and the old economic elites is strained, under the surface they are more often than not characterized by accommodation and consent than outright conflict. However, in the process there has been a gradual elite shift where groups that have benefited from the centre-left governments policies gradually gain influence at the expense of old rural and business elites. This has occurred in Argentina with the strengthening of agrienterprises; in Bolivia with the emerging soy elite; in Ecuador with the new cadres of technocrats in the ministries; and in a more incipient form in El Salvador with new elites related to ALBA investments. ${ }^{3}$

In addition to new governmental policies, we have found two factors to be of key importance to the emergence of new elites: knowledge 
and technology. Controlling capital or politics without also controlling knowledge and technology has shown to be insufficient to dominate the development agenda and the environmental governance of it. Knowledge and technology can be "bought" by those who control capital, but this is only partly true because it is necessary to have the sufficient knowledge, relevant technology and appropriate attitude towards innovation to know where to invest in it. Also, obtaining and making use of these resources are long-term processes. The corollary to that is that groups that control knowledge and technology may also influence environmental governance to an extent disproportionate to their political position or economic resources, as we have seen in the cases of the REDD networks, and in a different way in the Ecuadorean Ministry of Agriculture.

This may have positive and negative implications for the environment. The control of knowledge can be an obstacle to better environmental governance, such as when it is used by a technocracy to pursue an agenda that pays little attention to environmental or distributional concerns, or when it is controlled by a transnational company as a means to strengthen its own profit generation. However, it can also be used to influence the agenda in a more sustainable way, such as has been observed in the case of, for example, El Salvador, where groups of environmentalists with high levels of technical education were included in the government. In spite of not having achieved the influence that they had hoped for, they did influence parts of the governmental agenda to become more directed towards adapting to climate change and avoiding new environmental catastrophes induced by intensive export agriculture. The emergence of what could be called a "new, environmental technocratic elite" was also observed in other countries, including Chile and Bolivia (Reyes, 2012; Høiby and Zenteno Hopp, 2015). This new technocratic elite differs from other historical groups of technocrats, not only by being unified by a different body of knowledge from, for example, the neoliberal economists that constitute the technocrats supporting the neo-liberal conversion. They also show a different attitude towards relating to non-elite groups. Many have been involved in environmental movements at local, national and transnational levels, and many stay in touch with communities through everything from frequent visits to membership of Facebook groups. Although their actual influence varies, their strengthening may lead to stronger environmental governance over time. Moreover, where the government favours party cadres over technically competent officials in important positions, the likelihood that such "new technocracies" emerge 
diminishes as, for example, in the case of Argentina (Hanche-Olsen, 2013).

Yet it is impossible to ignore at least three "constants" in environmental governance in Latin America. One is the importance of global markets. During the last decade, Latin America as a region has made significant progress in a number of social indicators, but it has also reinforced its dependency on natural resource export, and therefore its vulnerability to changes in the global markets for a limited set of export goods. This is less so in Mexico and Central America than in South America, but across the region there is little in the way of a "structural transformation" towards a production structure dependant more on knowledge and innovation and less on cheap labour and natural resources. As noted by CEPAL (2014), without such a conversion, it will be difficult to sustain incipient processes towards a more just resource distribution, or to counteract the serious processes of environmental degradation.

The second "constant" is limitation in resources. For leftist governments with little support from, and often in conflict with, the economic elite, to stay in power and to implement ambitious programmes for societal transformation has required both to employ policies to strengthen the state and to confront the opposition from old elites. State-building has been an unavoidable priority for the centre-left governments in Latin America to be able to deliver strong programmes of resource redistribution to address historical inequalities, and in this way to lift millions out of poverty. Several strategies have been employed to face opposition from old elites: grooming new elites, confronting competing elites or allying with outside elites. Given that the international context has been very favourable for resource extraction, focusing on these sectors (particularly mining and agriculture) has allowed centreleft governments to increase their revenues and deliver their promises of resource redistribution. At the same time, larger revenues have permitted governments in Latin America to transform their relationships with traditional international elites (weakening their influence in domestic politics) and to enter into relationships with new international elites. In this context it can be said that leftist governments in Latin America have taken a pragmatic approach to be able to secure their position; this approach implies that, in development policy, economic revenues take precedence over environmental concerns. We can then affirm that the effects of the elite shift on environmental governance in Latin America have been limited thus far.

The third "constant" is the abyss between the traditional elite and non-elite groups in terms of the meaning given to nature and what 
constitutes a just governance of it, in terms of both processes and outcome. Although, as we have shown, the elites go through processes of change that lead to episodes of "elite circulation" as well as "elite conversion", we still find elite groups across the region with a very limited understanding of the local environmental impact of developmental projects, the importance and meaning of resources such as land and water to rural communities, and what it takes to actually reach understandings across cultural and class divides. Without this, reaching more sustainable and just environmental governance in Latin America may still be far away.

\section{Notes}

1. This approach focused on the conditions for - and evolution of - a state with a monopoly on legitimate violence, and an institutional bureaucracy capable of implementing policies and controlling the masses (e.g. Migdal et al., 1994; Evans, 1995). Such a state, in which a given set of institutions' right to tax and demand loyalty in return for protection and the extension of benefit are no longer questioned, is, for example, considered to be a precondition for the high-growth policies and business-state relationship of the East Asian developmental states (Amsden, 2001) as well as the more historical examples of development, such as that of Europe (Tilly, 1992).

2. He argued rather that "Between socialism as we defined it and democracy as we defined it there is no necessary relation" (Schumpeter, 1976: 284).

3. The tendency observed in El Salvador would probably have been more pronounced had we included Nicaragua and Venezuela in the study.

\section{References}

Acemoglu, D. and Robinson, J.A. (2012) Why Nations Fail? The Origins of Power, Prosperity and Poverty (London: Profile Books).

Aguilar-Støen, M. (2015) "Staying the Same: Transnational Elites, Mining and Environmental Governance in Guatemala", in B. Bull and M.C. AguilarStøen (eds), Environmental Politics in Latin America: Elite Dynamics, the Left Tide and Sustainable Development (London: Routledge Studies in Sustainable Development), 131-149.

Aguilar-Støen, M. and Hirsch, C. (2015) "REDD and Forest Governance in Latin America: The Role of Science-Policy Networks", in B. Bull and M.C. AguilarStøen (eds), Environmental Politics in Latin America: Elite Dynamics, the Left Tide and Sustainable Development (London: Routledge Studies in Sustainable Development), 171-189.

Alimonda, H. (2011) "La Colonialidad de la Naturaleza: Una Aproximación a la Ecología Política Latinoamericana", in H. Alimonda (ed.), La Naturaleza Colonizada: Ecología Política y Minería en América Latina (Buenos Aires: CLACSO).

Amsden, A. (2001) The Rise of "The Rest" Challenges to the West from LateIndustrializing Economies (Oxford: Oxford University Press). 
Amsden, A., Di Caprio, H.A. and Robinson, J.A. (2012) The Role of Elites in Economic Development UNI-Wider Studies in Development Economics (Oxford: Oxford University Press).

Andrade, P. (2012) "En el Reino (de lo) Imaginario: Los Intelectuales Ecuatorianos en la Creación de la Constitución de 2008", Ecuador Debate 85: 35-48.

Angelsen, A. and McNeil, D. (2012) "The Evolution of REDD+", in A. Angelsen, M. Brockhaus, W.D. Sunderlin and L.V. Verchot (eds), Analysing REDD+ Challenges and Choices (Bogor Indonesia: CIFOR).

Arretche, M. (2013) "Quando Instituições Federativas fortalecem o Governo Central?", Novos Estudos-CEBRAP 95: 39-57.

Ayo Saucedo, D. (2012) Nuevas Élites Económicas y su Inserción en la Política, Working Paper N 01 (La Paz: Foro de Desarrollo Friedrich Ebert Stiftung/Fundación Boliviana para la Democracia Multipartidaria).

Ayo Saucedo, D., Fernández Morales, M. and Kudelka Zalles, A. (2013) Municipalismo de Base Estrecha. La Guardia, Viacha, Quillacollo: La Difícil Emergencia de las Nuevas Élites (La Paz: PIEB).

Barri, F. and Wahren, J. (2010) "El Modelo Sojero de Desarrollo en la Argentina: Tensiones y Conflictos en la Era del Neocolonialismo de los Agronegocios y el Cientificismo-Tecnológico", Realidad Económica 255: 43-65.

Basabe, S., Pachano, S. and Acosta, A. (2012) "Ecuador: Democracia Inconclusa", in M. Cameron and J.P. Luna (eds), Democracia en la Región Andina (Lima, Peru: IEP).

Bebbington, A. and Bebbington, D. (2012) "Post-What? Extractive Industries Narratives of Development and Socio-Environmental Disputes Across the (Ostensible Changing) Andean Region", in H. Haarstad (ed.), New Political Spaces in Latin American Natural Resource Governance (London: Palgrave Macmillan), 17-38.

Benchimol, P. (2008) La Concentración de la Tierra, Latifundios y Agro-Societies, http://www.pagina12.com.ar/diario/suplementos/cash/17-3460-2008-04-20. html, date accessed 16 November 2013.

Bindraban, P.S., Franke, A.C., Ferraro, D.O., Ghersa, C.M., Lotz, L.A.P., Nepomuceno, A., Smulders, M.J.M. and Van de Wiel, C.C.M. (2009) GM-Related Sustainability: Agro-Ecological Impacts, Risks and Opportunities of Soy Production in Argentina and Brazil. Report 259 (Wageningen: Wageningen University - Plant Research International).

Block, F. (1977) "The Ruling Class Does Not Rule: Notes on the Marxist Theory of the State", Socialist Review 33: 6-27.

Bowen, J.D. (2011) "Multicultural Market Democracy: Elites and Indigenous Movements in Contemporary Ecuador", Journal of Latin American Studies 43(3): 451-483.

Bull, B. (2013) "Diversified Business Groups and the Transnationalisation of the El Salvadoran Economy", Journal of Latin American Studies 45(2): 265-295.

Bull, B. (2014) "Latin America's Decade of Growth: Progress and Challenges for a Sustainable Development", in A. Hansen and U. Wethal (eds), Emerging Economies and Challenges to Sustainability (London: Routledge), 123-134.

Bull, B. (2015) "Elites, Classes and Environmental Governance: Conceptual and Theoretical Challenges", in B. Bull and M.C. Aguilar-Støen (eds), Environmental Politics in Latin America: Elite Dynamics, the Left Tide and Sustainable Development (London: Routledge Studies in Sustainable Development), 15-32. 
Bull, B., Castellacci, F. and Kasahara, Y. (2014) Business Groups and Transnational Capitalism in Central America: Economic and Political Strategies (Houndmills, Basingstoke, Hampshire: Palgrave Macmillan).

Bull, B., Cuéllar, N. and Kandel, S. (2014) "El Salvador: The Challenge to Entrenched Elites and the Difficult Road to a Sustainable Development Model", in B. Bull and M.C. Aguilar-Støen (eds), Environmental Politics in Latin America: Elite Dynamics, the Left Tide and Sustainable Development (London: Routledge Studies in Sustainable Development), 33-50.

Bumpus, A.G. and Liverman, D. (2011) "Carbon Colonialism? Offsets Greenhouse Gas Reduction and Sustainable Development", in R. Peet, P. Robbins and M.J. Watts (eds), Global Political Ecology (New York: Routledge), 203-224.

Calvo, S., Salvador, M.L., Giancola, S., Iturrioz, G., Covacevich, M. and Iglesias, D. (2011) "Causes and Consequences of the Expansion of Soybean in Argentina", in H. El-Shemy (ed.), Soybean Physiology and Biochemistry (open access: InTech), 365-388.

Carruthers, D.V. (2008) Environmental Justice in Latin America: Problems, Promise and Practice (Cambridge MA: MIT Press).

CEPAL (2014) Pactos para la Igualdad: Hacía un Futuro Sostenible (Santiago, Chile: Comisión Económica para América Latina y el Caribe).

Cimoli, M. and Rovira, S. (2008) "Elites and Structural Inertia in Latin America: An Introductory Note on the Political Economy of Development", Journal of Economic Issues XLII(2): 327-347.

Dougherty, M.L. (2011) "The Global Gold Mining Industry, Junior Firms, and Civil Society Resistance in Guatemala", Bulletin of Latin American Research 30(4): 403-418.

Durán Lima, J. and Pellandra, A. (2013) "El Efecto de la Emergencia de China sobre la Producción y el Comercio en América Latina y el Caribe", in E. Dussel Peters (ed.), América Latina y El Caribe - China Economía Comercio e Inversiones (Mexico: UNAM).

Etzioni-Halevy, E. (1997) "Introduction", in E. Etzioni-Halevy (ed.), Classes and Elites in Democracy and Democratization (New York and London: Garland Publishing).

Evans, P. (1995) Embedded Autonomy States and Industrial Transformation (Princeton: University Press).

Fairhead, J. and Leach, M. (2003) Science Society and Power: Environmental Knowledge and Policy in West Africa and the Caribbean (Cambridge: Cambridge University Press).

Gudynas, E. (2010) "Si eres tan Progresista ¿Por qué destruyes la Naturaleza? Neoextractivismo, Izquierda y Alternativas", Ecuador Debate 79: 61-81.

Hall, A. (2012) Forests and Climate Change: The Social Dimensions of REDD in Latin America (London: Edward Elgar Publishing Ltd).

Hanche-Olsen, E. (2013) Argentine Farmers Search for Collective Action. A Case Study of Rural Cooperatives Within the Genetically Modified Agricultural Production in Argentina, unpublished master thesis Latin America Studies (Oslo: University of Oslo).

Hartmann, M. (2007) The Sociology of Elites (London: Routledge).

Hecht, S.B., Kandel, S., Gomes, I., Cuellar, N. and Rosa, H. (2006) "Globalization, Forest Resurgence and Environmental Politics in El Salvador", World Development 34: 308-323. 
Higley, J. and Gunther, R. (1992) Elites and Democratic Consolidation in Latin America and Southern Europe (Cambridge: Cambridge University Press).

Høiby, M. and Zenteno Hopp, J. (2015) "Bolivia: Emerging and Traditional Elites and the Governance of the Soy Sector", in B. Bull and M.C. AguilarStøen (eds), Environmental Politics in Latin America: Elite Dynamics, the Left Tide and Sustainable Development (London: Routledge Studies in Sustainable Development), 51-70.

Jessop, B. (1990) State Theory Putting Capitalist States in Their Place (Pennsylvania: Penn State University Press).

Lee, S.L. and Bonilla de Anzueto, M.A. (2009) Contribución de la Industria Minera al Desarrollo de Guatemala (Guatemala: Centro de Investigaciones Económicas Nacionales).

Lemos, A.L.F. and Arimatea Silva J. (2011) "Desmatamento na Amazônia Legal: Evolução, Causas, Monitoramento e Possibilidades de Mitigação Através do Fundo Amazônia", Floresta e Ambiente 18(1): 98-108.

Lemus, E. (2014) "La Milionaria Revolución de ALBA", El Faro 19 January 2014, http://www elfaro net/es/201401/noticias/14423/, date accessed 17 November 2014.

Loman, H. (2013) Country Report Argentina Rabobank, https://economics. rabobank.com/publications/2013/october/country/report/argentina/, date accessed 21 January 2014.

Martinez-Alier, J. (2002) The Environmentalism of the Poor: A Study of Ecological Conflicts and Valuation (Cheltenham: Edward Elgar Publishers).

Michels, R. (1962) Political Parties (New York: Free Press).

Migdal, J.S., Kohli, A. and Shue, V. (1994) State Power and Social Forces. Domination and Transformation in the Third World (Cambridge: Cambridge University Press).

Mosca, G. (1939) The Ruling Class (New York: McGraw Hill).

Myrdal, G. (1968) Asian Drama: An Inquiry into the Poverty of Nations (New York: Pantheon).

Myrdal, G. (2010 [1979]) "Underdevelopment and the Evolutionary Imperative", Third World Quarterly 1(2), reprinted in B. Bull and M. Bøås (2010), International Development, Volume II (London: Sage).

Paige, J. M. (1997) Coffee and Power Revolution and the Rise of Democracy in Central America (Cambridge, MA: Harvard University Press).

Pareto, W. (1997 [1935]) "The Governing Elite in Present-Day Democracy", in E. Eztioni-Halevy (ed.), Classes and Elites in Democracy and Democratization (New York and London: Garland Publishing).

Peet, R., Robbins, P. and Watts M. (eds) (2010) Global Political Ecology (London: Routledge).

Plata, W. (2008) "El Discurso Autonomista de las Élites de Santa Cruz", in X. Soruco, W. Plata and G. Medeiros (eds), Los Barones del Oriente. El Poder en Santa Cruz Ayer y Hoy (Santa Cruz, Bolivia: Fundación Tierra).

Poulantzas, N. (1978) State, Power, Socialism (New York: Verso).

Reyes, C. (2012) Las Elites y los Nadies: Caso de Estudio sobre la Influencia de la Elite Chilena en un Conflicto Ambiental, unpublished master thesis Latin America Studies (Oslo: University of Oslo).

Schneider, A. (2012) State-Building and Tax Regimes in Central America (New York: Cambridge University Press).

Schumpeter, J.A. (1976) Capitalism, Socialism and Democracy (London and New York: Routledge). 
Segovia, A. (2002) Transformación Estructural y Reforma Económica en El Salvador. El Funcionamiento Económico de los Noventa y sus Efectos sobre el Crecimiento la Pobreza y la Distribución de Ingreso (Guatemala: FandG Editores).

SENPLADES (2013) "Plan Nacional del Buen Vivir", República del Ecuador Consejo Nacional de Planificación (Quito, Ecuador: Secretaria Nacional de Planificación y Desarrollo).

Skill, K. and Grinberg, E. (2013) "Controversias Sociotécnicas en Torno a las Fumigaciones con Glifosato en Argentina. Una Mirada desde la Construcción Social del Riesgo", in G. Merlinsky (ed.), Cartografias del Conflicto Ambiental en Argentina (Buenos Aires: CLACSO and Fundación CICCUS).

Soruco, X. (2008) "De la Goma a la Soya: El Proyecto Histórico de la Élite Cruceña", in X. Soruco, W. Plata and G. Medeiros (eds), Los Barones del Oriente. El Poder en Santa Cruz Ayer y Hoy (Santa Cruz, Bolivia: Fundación Tierra).

Tilly, C. (1992) Coercion Capital and European States AD 990 - 1992 (Cambridge MA and Oxford UK: Blackwell Publishers).

Toni, F., Villarroel, L. and Taitson Bueno, B. (2015) "State Governments and Forest Policy: A New Elite in the Brazilian Amazon?", in B. Bull and M.C. Aguilar-Støen (eds), Environmental Politics in Latin America: Elite Dynamics, the Left Tide and Sustainable Development (London: Routledge Studies in Sustainable Development), 190-205.

Trigo, E. (2011) Fifteen Years of Genetically Modified Crops in Argentine Agriculture (Buenos Aires: ArgenBio).

USDA (2013) USDA Agricultural Projections to 2022, Long-Term Projections Report OCE-2013-1 (Washington: Office of the Chief Economist World Agricultural Outlook Board US Department of Agriculture/Interagency Agricultural Projections Committee).

Weber, M. (1978) Economy and Society (Berkeley: Berkeley University Press).

Wolf, A. (2012) "Two for the Price of One? The Contribution to Development of the New Female Elites", in A. Amsden, A. DiCaprio and J.A. Robinson (eds), The Role of Elites in Economic Development. UNI-Wider Studies in Development Economics (Oxford: Oxford University Press), 120-139.

Woo-Cumings, M. (ed.) (1999) The Developmental State (Ithaca, NY: Cornell University Press).

Zeballos, H. (2012) Bolivia: Desarrollo del Sector Oleaginoso 1980-2010 (Santa Cruz: Instituto Boliviano de Comercio Exterior - IBCE).

Zenteno Hopp, J., Hanche-Olsen, E. and Sejenovich, H. (2015) "Argentina: Government-Agribusiness Elite Dynamics and Its Consequences for Environmental Governance", in B. Bull and M.C. Aguilar-Støen (eds), Environmental Politics in Latin America: Elite Dynamics, the Left Tide and Sustainable Development (London: Routledge Studies in Sustainable Development), 71-91.

Zibechi, R. (2010) "América Latina: Nuevos Conflictos Viejos Actores", América Latina en Movimiento, http://alainet.org/active/39400, date accessed 10 November 2014 .

Except where otherwise noted, this work is licensed under a Creative Commons Attribution 3.0 Unported License. To view a copy of this license, visit http://creativecommons.org/licenses/by/3.0/ 